DOI 10.31558/2075-2970.2019.37.3

УДК [811.161.2+811.162.1]'367.625'373.611

(C) Л. В. Сегін

(Слов'янськ)

\title{
СТРУКТУРНО-СЕМАНТИЧНІ ОСОБЛИВОСТІ СЛОВОТВІРНОЇ ПАРАДИГМИ ПРЕФІКСАЛЬНИХ ДІССЛІВ ІЗ ЗНАЧЕННЯМ НАБЛИЖЕННЯ В УКРАЇНСЬКІЙ І ПОЛЬСЬКІЙ МОВАХ
}

У статті проаналізовано структурно-семантичні особливості типової словотвірної парадигми префіксальних дієслів динамічної просторової локалізованості із значенням віддалення в українській і польській мовах. 3'ясовано, що для досліджуваних префіксальних дієслів характерна чотиризонна типова словотвірна парадигма з 13 словотвірними значеннями («опредметнена дія», «знаряддя дії», «місце дії», «виконавець дії», «об’єкт дії», «ознака об’єкта за дією», «ознака суб’єкта за дією», «призначений для того, на що вказує твірна основа», «дистрибутивність дії», «виконуючи дію, переводити щось із стану об’єкта в стан суб'єкта», «однократність дії», «кумулятивність дії», «адвербіалізація дії»). Виявлено, що досліджувані дієслова української мови породжують похідні чотирьох частиномовних блоків, а девербативи реалізують 11 словотвірних значень типової словотвірної парадигми. Серед девербативів польської мови виявлено іменники, ад’єктиви та дієслова, тобто типова словотвірна парадигма складається 3 трьох блоків з 10 семантичними позиціями. Спільними для обох мов є 9 словотвірних значень, однак окремі семантичні позиції заповнені лише в одній із мов («однократність дії», «адвербіалізація дії» - в українській мові; «місце дії», «кумулятивність дії» - у польській мові). Констатовано, що частиномовні блоки польської мови вдвічі більше кількісно наповнені, більша в польській мові й максимальна глибина семантичної позиції «опредметнена дія» та лише поодинокі твірні не породжують похідні.

Ключові слова: словотвірна парадигма, словотвірний потенціал, словотвірне значення, девербатив, словотворчий формант.

Liubomyr Sehin STRUCTURAL AND SEMANTIC FEATURES OF THE WORD-FORMATION PARADIGM OF PREFIXAL VERBS WITH THE MEANING OF APPROXIMATION IN THE UKRAINIAN AND POLISH LANGUAGES

Abstract. The author analyzes the structural and semantic features of a typical word-formation paradigm in prefixal verbs of dynamic spatial localization with the meaning of estrangement in the Ukrainian and Polish languages. It was found that the studied prefixal verbs are characterized by a four-zone typical word-formation paradigm with 13 word-formation meaning ("objectified action", "instrument of action", "place of action", "performer of action", "object of action", "indication of an object by action", "subject's characteristic by action", "intended for what the derivational stem indicates", "distributivity of action", "when performing an action, to transfer something from the object's state to the subjects state", "one-time action", "cumulativity of action", "adverbialization of action"). It is revealed that the studied Ukrainian verbs give rise to derivatives of four part-of-speech blocks, and the deverbatives show 11 word-formation meanings of a typical word-formation paradigm. Derivatives of nouns, adjectives, and verbs were found among the derivatives of the Polish deverbatives, 
i. e. a typical word-formation paradigm consists of three blocks with 10 semantic positions. In both languages, derivatives of 9 word-formation meanings are registered, but certain semantic positions are filled only in one of the languages ("single action", "adverbialization of action" in Ukrainian; "place of action", "cumulativity of action" in Polish). It is stated that part of speech blocks in Polish are twice as numerous as in Ukrainian; the depth of the semantic position within the meaning "objectified action" is bigger in Polish as well; only rare derivational stems do not generate derivatives.

Key words: word-formation paradigm, word-formation potential, word-formation meaning, deverbative, word-formation formant.

\section{1. Вступ}

Останнім часом посилюється увага до дослідження словотвірного потенціалу слів різних частин мови, особливе місце серед яких займає дієслово. На сьогодні проаналізовано дериваційні спроможності дієслів на матеріалі словацької (Buzassyova, 1974), російської (О. М. Тихонов, Т. С. Морозова, Т. В. Чиканцева, Т. С. Яруліна, С.М.Бразаускене та ін.), української (Н. Ф. Клименко; С. А. Карпіловська; М. П. Лесюк; В. В. Грещук та ін., 2007; Валюх, 2005; Кушлик 2015 та ін.), білоруської (О. О. Лукашанець), польської (М. Беренд, Р. Гжегорчикова, М. Скажинський, Г. Ядацька та ін.) мов тощо.

Проте досить часто поза увагою дослідників залишається вивчення словотвірних можливостей частин мови, лексико-семантичних груп у зіставно-типологічному аспекті. Так, Н. Ф. Клименко та 3. О. Валюх зазначають, що серед важливих проблем української дериватології, які потребують теоретичного осмислення, є комплексний аналіз словотвірних категорій та їх типологія й зіставлення в споріднених і неспоріднених мовах (Клименко, 1991, с. 81; Валюх, 2013, с. 6). Дериватологи висловлюють думку, що найбільш повно відображає словотвірні можливості окремих слів певної частини мови або лексико-семантичних груп як твірної бази така комплексна словотвірна одиниця, як словотвірна парадигма, яку трактують як сукупність дериватів, що мотивовані тим самим твірним і перебувають на одному ступені похідності (Buzassyova, 1974, с. 231-232; Земская, 1978; Клименко, 2004, с. 619; Грещук та ін., 2007, c. 10, Валюх, 2005, с. 31 та ін.). На думку О. А. Земської, словотвірна парадигма є найбільш зручним об'єктом зіставлення, оскільки найяскравіше показує системний характер словотвору (Земская, 1993, с. 250). Наразі в мовознавстві присвячено тільки поодинокі праці зіставнотипологічного вивчення словотвірних можливостей дієслів на рівні словотвірної парадигми окремих мов: російської і вірменської (Р. С. Манучарян), російської, польської і чеської (Т. А. Ацаркіна), української і польської (Л. В. Сегін, 2003), української, російської і польської (Н. О. Ярошенко), польської і чеської (Malankowska-Statkiewicz, 2017), польської і болгарської (В. Малджиєва), російської і німецької (Т. І. Скоробагата). Спеціального комплексного дослідження словотвірного потенціалу хоча б окремих лексико-семантичних груп дієслів сучасних слов'янських мов у зіставно-типологічному зрізі поки що немає. Саме тому такий аналіз видається актуальним і на часі.

Мета статті - проаналізувати структурно-семантичні особливості типової словотвірної парадигми дієслів із значенням наближення в українській і польській мові. Мета вимагає розв'язання таких завдань: 1) визначити структурну типологію досліджуваних девербативів; 2) встановити континуум словотвірних значень, реалізованих похідними від префіксальних дієслів; 3) прослідкувати глибину семантичної позиції; 4) з'ясувати кількісну наповнюваність 
кожного структурного блоку, словотвірного значення; 5) виявити спільні і специфічні ознаки у реалізації словотвірного потенціалу досліджуваних дієслів у зіставлюваних мовах.

Матеріалом для дослідження слугували девербативи української і польської мов, отримані методом суцільної вибірки з найавторитетніших лексикографічних джерел (СУМ, СУМГ, ВТССУМ, ВЗОССУЛ, SJPK, SJPD, SGSWJO). Обсяг вибірки склав 625 одиниць, з яких 132 твірних (укр. - 60; пол. - 72) та 493 похідних (укр. - 162; пол. - 331) дериватів в обох мовах.

\section{2. Виклад матеріалу}

Дієслова із значенням наближення є однією з найбільш чисельних груп в українській i польській мовах. На думку Н. І. Грицик, спільність значення дієслів наближення знаходить своє відображення також у наявності спільної для всіх членів макрополя формули «дієслово + до + іменник в Р. в.» (Грицик, 1980, с. 83). Цей актант зі значенням кінцевої точки руху, за словами С. О. Соколової, є обов'язковим із семантичного погляду, але в реченні може бути відсутнім і відновлюватися з ширшого контексту (Соколова, 2003, с. 161).

Як відомо, параметри конкретних словотвірних парадигм дієслів залежать від лексичних i семантико-граматичних особливостей вершинного слова, його структури, семантико-синтаксичних зв’язків, активності та сфери функціонування. Тому доцільним, на нашу думку, є вивчення твірних слів за цими параметрами. На основі аналізу твірних дієслів із значенням наближення можна стверджувати, що всі деривати є віддієслівного походження, які утворюються за допомогою префіксації: укр. доступити / доступати (розм.) 1, зсунути, ізсунути (рідко) / зсувати, ізсувати (рідко), зсовувати, ізсовувати (рідко) 2, а, надбігти / надбігати 1, надлетіти / надлітати (розм.) 1a, під 'їхати / під’їжджати, під’їзити 1, a, підкрастися / підкрадатися 1, підсунути/ підсувати, підсовувати 2, притягти, притягнути / притягати, притягувати 1 та ін.; пол. dojechać / dojeżdżać 1, dosunać / dosuwać, nadbiec, nadbiegnać (rzad.), nadbieżeć/ nadbiegać2, nadciagnać / nadciagać (przestarz.) $1 \mathrm{a}, \mathrm{b}$, nadlecieć / rzad. nadlatać, nadlatywać 1, podejść / podchodzić 1,3, podkraść się/ podkradać się, podnieśćl podnosić 3 , przykroczyć / przykraczać, przytoczyć / przytaczać 1 та ін.

Особливістю префіксації $\epsilon$ те, що мотиватором у внутрішньодієслівному префіксальному словотворі виступає не основа, а ціле дієслово, яке зберігає свої граматичні характеристики, крім виду (Соколова, 2003, с. 6). Деривати із значенням наближення утворюються поєднанням переважно дієслів односпрямованого руху та префікса, який конкретизує спрямування суб'єкта і водночас перфективує дієслова. Від префіксальних дієслів із значенням наближення доконаного виду утворюються дієслова недоконаного виду за допомогою суфіксів -а-, -ува-, напр., надбігти - надбігати 1, підкотити / підкочувати 1 1, 2, nідповзти / підповзати 1, nadlecieć / nadlatać (rzad.), nadlatywać 1, podpędzić / podpędzać 1 і под., які розглядаємо як тотожні за значенням, але різні за видом. У наведених парах кореляти недоконаного виду вважаємо такими, що виникли шляхом імперфективації (Граматика, 2017, с. 396-397; Грицик, 1979, с. 71-72; Соколова, 2003, с. 71). В українській мові дієслова зі значенням наближення утворюються за допомогою префіксів під-, при-, над-, з-(c-), на-, за-, до- (префікси подано за зниженням їхньої продуктивності), у польській мові - завдяки формантам pod-, przy-, nad-, do-, z-(s-), u-, na-, ob-, za-. Така різноманітність префіксів зумовлена тим, що дієслова руху здатні приєднувати всі дієслівні префікси, а деякі префікси в певному значенні поєднуються тільки з дієсловами руху, що є їх прикметною ознакою (Сайкиева, 1970, с. 8). 
Продуктивність афіксів у творенні дісслів наближення в українській і польській мовах

\begin{tabular}{|c|c|c|c|c|}
\hline $\begin{array}{l}\text { № } \\
\text { 3/II }\end{array}$ & Афікс & $\begin{array}{l}\text { Кількість дісслів } \\
\text { із цим афіксом }\end{array}$ & $\%$ & Приклади \\
\hline 1 & під-/pod- & $27 / 24$ & $45 / 33,3$ & підкотити 1,2, podciagnąć 3 \\
\hline 2 & при-/przy- & $10 / 21$ & $16,6 / 29,1$ & пристрибати 1 , przytoczyć 1 \\
\hline 3 & над-/nad- & $6 / 9$ & $10 / 12,5$ & надбігти 1, nadlecieć 1 \\
\hline 4 & 3-(c-)/ z-(s-) & $6 / 3$ & $10 / 4,1$ & зсунути, skraść si \\
\hline 5 & на-/na- & $4 / 1$ & $6,6 / 1,3$ & насунути 4a, nasunać 4 (rzad.) \\
\hline 6 & 3a-/za- & $3 / 1$ & $5 / 1,3$ & залетіти / залітати 3a, zajść / zachodzić 2 \\
\hline 7 & до-/do- & $3 / 8$ & $5 / 11,1$ & $\begin{array}{c}\text { доступити / docmynamu (розм.) 1, dojechać / } \\
\text { dojeżdżać } 1\end{array}$ \\
\hline 8 & po- & 2 & 2,7 & postapić / postępować 1 \\
\hline 9 & $\mathrm{u}-$ & 2 & 2,7 & uwlec / uwlekać (daw.) d \\
\hline 10 & ob- & 1 & 1,3 & objechać / objeżḋ̇ać 4 (łow.) \\
\hline 11 & c- ся & 1 & 1,6 & сходитися 16,2 \\
\hline \multicolumn{2}{|r|}{ Всього } & $60 / 72$ & 100 & \\
\hline
\end{tabular}

Як бачимо, зіставлювані мови відрізняються кількісним набором префіксів, що беруть участь у реалізації цього структурного типу твірних, виявлено як спільні префікси для обох мов, так і характерні для однієї з мов. Найбільш продуктивними в утворенні дієслів наближення в зіставлюваних мовах виступають префікси під- / pod-, при- / przy-. Малопродуктивним $є$ формант над- / nad-, що, на думку С. О. Соколової, можна пояснити тим, що спільнокореневі дієслова з префіксом над- і під- у цьому значенні (якщо можливі обидва префіксальні утворення) є дуже близькими синонімами, фактично їх можна вважати дублетами, але сполучуваність префікса під- з дієслівними основами значно ширша (Соколова, 2003, с. 163). Деривати з префіксами на- / na-, за- / za-, до-, з- (c-) / z- (s- ), po-, ob- представлені кількома одиницями. Серед продуктивних (при- / przy-) і непродуктивних префіксів (до- / do-) впадає в око значно більша кількість дієслів у польській мові. Це зумовлено тим, що, з одного боку, в значенні польських дієслів з префіксом przy- фіксуємо і значення наближення, і значення прибуття, тоді як в українських еквівалентах - лише значення прибуття, пор.: пол. przybiec, przybieżé (daw.), przybiegnać / przybiegać1 - zbliżyć się, przybyć, zdążyć do oznaczonego miejsca biegnąć (SJPD); укр. прибігти / прибігати - 'бігом досягати якого-небудь місця', 'поспішно приходити до когось, кудись', розм. 'прибувати з поспіхом куди-небудь верхи на коні або в екіпажі', перен., розм. 'негайно з'являтися куди-небудь' (ВТССУМ, с. 924). 3 іншого боку, українські еквіваленти польських твірних із префіксом dо- зазвичай реалізують тільки значення прибуття, пор.: пол. dojechać / dojeżdżać1 - 'jadąc, zbliżyć się do kogo lub do czego' (SJPD), dociagnać / dociagać 1,3,5 - 'ciągnąć, wlokąc przybliżać co (kogo) do pewnego miejsca, kresu', 'idąc, jadąc, lecąc zbliżać się do jakiegoś miejsca’ (SJPD); дойхати / доӥздти, доӥжджати - “їдучи, добиратися до чого-небудь' (ВТССУМ, с. 235), дотягти, дотягнути / дотягати, дотягувати - 'тягнучи кого-, що-небудь, доставляти до певного місця', 'ледве дійти, доїхати, насилу добратися куди-небудь, до чого-небудь’ (ВТССУМ, с. 244) і под.

Водночас у зіставлюваних мовах спостерігаємо, що між кількістю афіксів, які беруть участь у творенні девербативів, і кількістю префіксальних дієслів немає прямої залежності. 
Так, в українській мові за допомогою 8 префіксів утворено 60 префіксальних дієслів, а в польській мові на долю 10 префіксів припадає 74 деривати. 3 цього випливає, що в кожній мові групи можна обрахувати середню продуктивність одного афікса як співвідношення загальної кількості префіксальних дієслів до кількісного набору афіксів, що беруть участь у реалізації того чи того словотвірного значення. Наприклад, в українській мові середня продуктивність афікса при утворенні префіксальних дієслів зі значенням віддалення складає $60: 8=7,5$, а в польській $-72: 10=7,2$. На основі цього можна зробити висновок, що середня продуктивність українського афікса вища від польського $(7,5: 7,2)$.

Крім того, що дієслова ДПЛ активно поєднуються з префіксами, вони також продуктивні в утворенні девербативів. Українські префіксальні дієслова із значенням наближення породжують 162 девербативи різних лексико-граматичних класів, польські - 331. Середня кількість дериватів на одне мотивувальне слово в українській мові припадає 2,7 одиниці, у польській мові - 4,4 девербатива.

Таблиия 2

Продуктивність префіксальних дісслів із значенням наближення

\begin{tabular}{|c|c|c|c|}
\hline $\begin{array}{c}\text { Зіставлювані } \\
\text { мови }\end{array}$ & $\begin{array}{c}\text { Кількість } \\
\text { твірних }\end{array}$ & $\begin{array}{c}\text { Кількість } \\
\text { похідних }\end{array}$ & $\begin{array}{c}\text { Середня } \\
\text { кількість дериватів в одній СП }\end{array}$ \\
\hline Українська & 58 & 162 & 2,7 \\
\hline Польська & 74 & 331 & 4,4 \\
\hline
\end{tabular}

3 метою узагальнення і виявлення закономірності побудови словотвірних парадигм усіх вилучених для аналізу префіксальних дієслів використовуємо запропонований О. А. Земською термін «типова словотвірна парадигма», яку формують конкретні парадигми з однаковим набором дериваційних значень (Земская 1978, с. 73). У структурі словотвірної парадигми виділяємо блоки, тобто сукупності словотвірних значень, виражені дериватами однієї й тієї ж частини мови. Типова словотвірна парадигма префіксальних дієслів із значенням наближення складається з чотирьох блоків - субстантивного, ад'єктивного, вербального й адвербіального, тобто типову словотвірну парадигму аналізованих префіксальних дієслів формують словотвірні значення чотирьох лексико-граматичних класів: іменники, прикметники / дієприкметники, дієслова та прислівники.

Серед зібраних похідних від префіксальних дієслів наближення найбільше виявлено іменників. М. Янценецька, аналізуючи словотвірні можливості дієслів у породженні похідних іменників, наголошує на синтагматичному характері прояву його семантики, адже саме поняття дії розкривається в семантичних відносинах суб'єкта та об'єкта (Янценецкая, 1991), які на словотвірному рівні можуть бути виражені похідними іменниками за допомогою морфем.

Типова словотвірна парадигма дієслів наближення в межах субстантивного блоку представлена двома типами словотвірних значень: мутаційними та модифікаційними. Серед мутаційних похідних від префіксальних дієслів із значенням наближення виділяємо такі: «виконавець дії», «знаряддя дії», «об'єкт дії», «місце дії».

На відміну від інших семантичних груп динамічної просторової локалізованості дієслова зі значенням наближення не так продуктивно породжують похідні зі значенням «виконавець дії», реалізуючи правобічну суб'єктну валентність, оскільки «дієслова цього семантичного класу позначають фізичну трудову діяльність, а поняття діяльності передбачає діяча» (Хами- 
дуллина, 1981, с. 72). Змістова структура цих іменників побудована за схемою «той, хто наближає / наближається», наприклад: підганяльник - той, хто кого-небудь підганяє, підношувач - той, хто що-небудь підносить, podsuwacz - ten, co podsuwa, przyganiacz- ten, со przygania та ін. На думку А. М. Хамідуліної, «агентивні найменування такого типу з'явилися в результаті чистого транспонування дієслівного змісту» (Хамидуллина, 1981, с. 71). Засобами реалізації цього словотвірного значення виступають суфікси -ач / -acz, -ник (-льник), -шик, ciel, -c-: укр. підношувач, підштовхувач, підвідник, підганяльник, піднощик; пол. родsишасz, przyciagacz, przyganiacz, podrzuciciel, przystapiciel, przystępca.

Поодинокі деривати в обох мовах зафіксовано зі словотвірними значеннями «знаряддя дії», на вираженні якого спеціалізуються суфікси -ач / -acz, -ець, -к-, -nic-, -dl-, -ark- (укр. nidштовхувач, підтягач, приступець, приступка; пол. przyciagacz, podsuwka, podsuwnica (techn.), podjazdka, podsuwadło (chir.), przyciagarka (techn.)), та «об'єкт дії», засобами реалізації якого $\epsilon$ афікси -ок / -ek, Ø, -к- (укр. підчалок; пол. podrzutek, podsuw 2 (mało używ.), podsuwka 1 (gwar.)). Словотвірне значення «місце дії» виявлено лише в польській мові (пол. Dojazd2, dojście 2, objazd 3, 4 (daw.), objazdka 3, objaźdżka 2, przybliż (mało używ.), podjazd 2).

Значно більшою кількістю представлені транспозиційні деривати, які реалізуються в словотвірному значенні «опредметнена дія». Іменники із цим значенням утворюються від 41/68 твірних дієслів аналізованої групи, що складає 68,3 \% в українській і 91,8 \% польській мові відповідно. Найпродуктивнішим засобом реалізації цього значення в зіставлюваних мовах виступає суфікс -нн'- (-енн'-) / -n'- (-en'-): укр. заїжджання, зближання, зближення, зближування, підганяння, під’їджання, підкочування, піднесення, підношення, підстрибування, прискакування та ін.; пол. dociaganie, doganianie, dognanie, dogonienie, nadchodzenie, nadlecenie, nadlatywanie, podjechanie, podjeżżanie, podplywanie, podpłynienie, przykraczanie, przykroczenie, przytaczanie, przytoczenie та ін. Має рацію Н. Ф. Клименко, яка наголошує на зростанні кількості абстрактної лексики (назв абстрактних дій, процесів, станів, якостей, відношень) ..., збільшенні продуктивності словотворчих формантів, що виражають абстрактні поняття (типу -уванн(я), -анн(я), -енн(я), -изаці(я)...) (Клименко, 2008, с. 136). Свідченням цього $є$ іменники зі значенням «опредметнена дія», які не зафіксовано в тлумачних словниках української мови: наближування, насовування, підкрадання, підскакування, підсовування, підтаскування, прискакування, пристрибування та ін. (ВЗОССУЛ).

Продуктивним в обох мовах у творенні іменників з опредметненим значенням $є$ також нульовий суфікс: укр. заліт, зсув 2 (техн.), підвід (рідко), підгін 1, під’їд 1, підліт, піднос 1, підскік, підскок, підстуn 1 та ін.; пол. dojazd 1, doskok, nadbieg, podchód, podlot, podstęp2 (daw.), podsuw (mało używ.), przychód 3 (daw.), przyskok та ін., а в польській мові й суфікс -с'-: dociagnięcie, dosunięcie, nadbiegnięcie, nadejście, nadpłynięcie, podfrunięcie, podźwignięcie, przyczołgnięcie się, przysunięcie та ін. Непродуктивним формантом в обох мовах $є$ суфікс -к-: укр. підводка1; пол. skradka (staropol.).

Іменники зі словотвірним значенням «опредметнена дія» відзначаються найбільшою глибиною місць у словотвірній парадигмі. Максимальна глибина семантичної позиції сягає 3 дериватів у словотвірній парадигмі 1 дієслова (підвести / підводити 1, а, б) української мови та 5 дієслів (dopaść / dopadać 1, nadbiec, nadbiegnać (rzad.), nadbieżeć / nadbiegać 2, podejść / podchodzić 1, 3, podsunać / podsuwać 1, przyjść / przychodzić 1) в польській мові. Слів, що реалізують одне словотвірне значення, може бути одне або кілька. Залежно від кількості похідних 
iз різними формантами, що мають одне й те ж словотвірне значення, виділяють семантичні позиції одночленні, двочленні і т. д. В українській мові найбільше зафіксовано одночленних рядів словотвірних синонімів із словотвірним значенням «опредметнена дія», які виявлено в 28 словотвірних парадигмах, а в польській мові - двочленних рядів у 38 дериваційних парадигмах префіксальних дієслів. Похідні зі спільною основою в таких рядах перебувають у різних лексико-семантичних і функціонально-стилістичних відношеннях. Одні з них збігаються за своїми особливостями, тобто є дублетами, інші мають певні розбіжності. Повністю збігаються за своєю семантикою такі девербативи зі значенням «опредметнена дія»: укр. залітання, заліт; підганяння, підгін; під '̈̈джсання, під'їз; підлітання, підліт; підсування, підсовування, підсув; підтягання, підтягнення, підтягування, підтяжка та ін.; пол. dojechanie, dojeżḋanie, dojazd; dociaganie, dociagnięcie; nadciaganie, nadciagnienie, nadciagnięcie; podfruwanie, podfrunięcie; dojście 1, dochodzenie; podpłynienie, podptnięcie та ін. Частина девербативів відрізняється функціонально-стилістичними параметрами: укр. зсовування, зсування, зсув 2 (техн.); підведення, підводження, підвід (рідко), підводка 1; піднесення, підношення (рідко), піднос; підскакування, підскок, підскік; пол. doskakiwanie, doskoczenie, doskok 2 (sport.); dosunięcie, dosuwanie, dosuw (techn.); nadbieg (daw.), nadbiegnięcie, nadbieganie; nadchodzenie, nadejście, nadchód (mało używ.); podjazd1 (rzad.), podjechanie та ін.

Таблиия 3

Глибина місць С3 «опредметнена дія»

\begin{tabular}{|l|c|c|c|c|}
\hline \multirow{2}{*}{\multicolumn{2}{|c|}{ Типи позицій }} & \multicolumn{4}{|c|}{ Мови } \\
\cline { 2 - 5 } & \multicolumn{2}{|c|}{ украӥнська мова } & \multicolumn{2}{c|}{ польська мова } \\
\hline Одночленні & 28 & 71,7 & 21 & 32,8 \\
\hline Двочленні & 10 & 25,6 & 38 & 59,3 \\
\hline Тричленні & 1 & 2,5 & 5 & 7,8 \\
\hline & $\mathbf{3 9}$ & $\mathbf{1 0 0} \%$ & $\mathbf{6 4}$ & $\mathbf{1 0 0} \%$ \\
\hline
\end{tabular}

Ад’єктивний блок типової словотвірної парадигми префіксальних дієслів із значенням наближення порівняно зі субстантивним репрезентовано меншою кількістю дериватів (укр. 33 (20,3 \%), пол. - 68 (20,5 \%)) і представлений словотвірними значеннями «ознака об'єкта за дією», «ознака суб’єкта за дією», «призначений для того, на що вказує твірна основа».

Словотвірне значення «ознака об'єкта за дісю» представлене найбільшою кількістю похідних в обох мовах (укр. - 21; пол. - 52): укр. зсунений, зсунутий, наближений, підведений, підсунений, підсунутий, притягнений, притягнутий, притягуваний та ін.; пол. родерсhапу, роdepchnięty, podtoczony, podtaczany, przysunięty, przysuwany, przybliżany, zsunięty, zsuwany, objechany та ін., що зумовлено, за словами дослідників, «відповідною кількістю об'єктів позамовної дійсності, дію яких специфічно передає ад'єктив», а «сема дії, втілена у граматичні форми... ад'єктива, зберігає свій зміст, однак під впливом форми ад'єктива сприймається не як дія, а як ознака» (Безпояско та ін., 1993, с. 133). Похідні цієї семантичної позиції реалізують об'єктну валентність твірних дієслів: притягнути гілку $\rightarrow$ притягнена (притягнута) гіл$\kappa a$, підсунути стілець - підсунутий (підсунений) стілець, przytoczyć wóz $\rightarrow$ przytoczony wóz, podnieść wiadro $\rightarrow$ podniesiony wiadro тощо. Змістова структура дієприкметників і прикметників має спільну рису - дія «означає» предмет, тобто особливості або властивості дії, спрямованої на предмет, стають ознакою предмета (Безпояско та ін., 1993, с. 134). 
Сегін л. В.

Структурно-семантичні особливості словотвірної парадигми префіксальних дієслів із значенням наближення 6 украӥнській $i$ польській мовах

Словотвірне значення «призначений для того, на що вказує твірна основа» реалізує валентність знаряддя твірних дієслів, представлене 6 ад'єктивами української мови та 1 в польській: зсувальний, підганяльний, під'їзний, підштовхувальний, притягальний, притягувальний; пол. podjezdny.

Суб'єктні актанти аналізованих дериватів об'єктивують деривати зі словотвірним значенням «ознака суб'єкта за дісю», засобами реалізації якого виступають суфікси -н- / -n-, -юч- / -а̨с-, -л-/ -1- (укр. доступний 3, зсуваючий, над’їжджаючий, напливаючий, підлилий; пол. dostępny, dochodzacy, nadbiegły, nadeszły, podlazły, przypełzły, przystepowały). На думку Н. Д. Арутюнової, прикметники, які реалізують субстанціональну валентність, поєднуються тільки $з$ дієсловами конкретної семантики (Арутюнова 1976, с. 157-159). Поділяємо думку тих дослідників, які зазначають, що незначна кількість серед похідних із цим словотвірним значенням зумовлена тим, що аналізовані прикметники рідко сполучаються з іменами на позначення людини в українській мові.

У структуруванні словотвірних парадигм префіксальних дієслів із значенням наближення беруть участь і дієслова, які формують вербальний блок, який представлений 42 дериватами української мови та 76 девербативами польської. 3-поміж них виділяємо префіксальні, суфіксальні і постфіксальні девербативи. Дієслівний блок словотвірної парадигми досліджуваних дієслів репрезентують деривати із словотвірними значеннями «дистрибутивність дії», «виконуючи дію, переводити щось із стану об’єкта в стан суб'єкта», «кумулятивність дії», «однократність дії».

Префіксальні дієслова зіставлюваних мов зі значенням наближення є продуктивними в утворенні девербативів із словотвірним значенням «за допомогою дії, названої діссловом, наблизити(ся) усіх чи багатьох». Кількісно дериватів із цим значенням у польській мові виявлено вдвічі більше порівняно з українською (пор.: укр. - 20; пол. - 46): укр. подоганяти, позаходити, позсувати, позсовувати, попідбиратися, попідбігати, попідкочувати, попідкрадатися, попідносити, попідпливати, попідтягати, попідходити, поприскакувати, поприсувати та ін.; пол. podociagać, podoskakiwać, ponadbiegać, ponadlatywać, ponadpływać, popodfruwać, popodłazić, popodnosić, popodpetzać, popodplywać, popodrzucać, popodskakiwać, popodstęować, poprzybiegać, poprzyblizać, poprzyciagać, poprzychodzić, poprzylatać, poprzypetzać, poprzyskakiwać, poprzysuwać, poprzytaczać, pozblizać та ін.

У словотвірному значенні «виконуючи дію, переводити щось із стану об'скта в стан суб'єкта» актуалізовані дієслова з відоб'єктним значенням. За словами Р. П. Михайлик, усім дієслівним утворенням зі словотвірно-граматичною функцією характерне загальне значення «зосередженість, замкнутість дії на суб'єктові, що виступає носієм предикатної ознаки» (Михайлик, 1995, с. 8). Деривати з таким значенням засвідчені від 13 каузативних дієслів зі значенням наближення в обох мовах: укр. зблизитися / зближатися, зближсуватися, наблизитися / наближатися, наближуватися, насунутися / насуватися, насовуватися, підкотитися / підкочуватися, підсунутися / підсуватися, підсовуватися 1, а, підтягтися, підтягнутися / підтягатися, підтягуватися 2, приблизитися / приближуватися, присунутися / присуватися, присовуватися та ін. пол. dosunać się / dosuwać się, podsunać się / podsuwać się, podtoczyć się I podtaczać się, przyblizyć sięl przyblizać się, przysunać sięl przysuwać się, przytoczyć sięl przytaczać się, ubliżyć się / ubliżać się, zbliżyć się / zbliżać się1, zsunać się / zsuwać się та ін. 
Префіксальні дієслова зі значенням наближення приєднують префікс на-, утворюючи девербативи із кумулятивним значенням (napodciagać, napodnosić, napodprowadzać, naprzyganiać, naprzysuwać, naprzytaczać, naubliżać, nazbliżá́, nazsuwać та ін.), яке реалізують дієслова наближення тільки польської мови, та суфікс -ну-, утворюючи девербативи зі значенням «однократність дії» (підплигнути, підстрибнути, підштовхнути), яке виявлено лише в українській мові

Адвербіальний блок типової СП аналізованих префіксальних лексем сформований словотвірним значенням «адвербіалізація дії» і представлений дериватами підбігцем (розм.), підкрадьком (орф.), підлетом (рідко), підскоком (розм.), підстрибом (розм.), підстрибием (розм.), прискоком (орф.), прискаком (діал.), пристрибом та ін.

Не зафіксовано похідних дериватів у 12 (20,6 \%) словотвірних парадигмах дієслів української (надлетіти / надлітати (розм.) 1а, надпливти, надплисти / надпливати (розм.) 1a, надскочити / надскакувати (розм.) 1, підбасувати (розм.), підикутильгати (розм.), прикрастися / прикрадатися (рідко) та ін.) та 2 (2,7\%) польської мови (nadpetznać / nadpetzać, przydeptać), тобто їхні словотвірні парадигми виявилися нульовими, що зумовлено переважно стилістичним маркуванням твірних.

Таблиия 4

Кількісний розподіл за частинами мови

\begin{tabular}{|c|c|c|c|c|}
\hline \multirow[t]{2}{*}{ Частини мови } & \multicolumn{2}{|c|}{ Українська мова } & \multicolumn{2}{|c|}{ Польська мова } \\
\hline & к-сть & $\%$ & к-сть & $\%$ \\
\hline іменники & 76 & 46,9 & 187 & 56,4 \\
\hline прикметники / дієприкметники & 33 & 20,3 & 68 & 20,5 \\
\hline дієслова & 42 & 25,9 & 76 & 22,9 \\
\hline прислівники & 11 & 6,7 & - & - \\
\hline Всього & 162 & 100 & 331 & 100 \\
\hline
\end{tabular}

\section{3. Висновки}

Типова словотвірна парадигма дієслів із значенням наближення складається з чотирьох блоків і їі формують 13 словотвірних значень. Досліджувані дієслова української мови породжують похідні чотирьох частин мови (іменник, прикметник, дієслово, прислівник), а похідні девербативи реалізують 11 словотвірних значень типової словотвірної парадигми. Серед девербативів польської мови виявлено іменники, ад'єктиви та дієслова, тобто типова словотвірна парадигма на відміну від української складається з трьох блоків з 10 семантичними позиціями. В обох мовах зафіксовано похідні 9 словотвірних значень, однак окремі семантичні позиції заповнені лише в одній із мов («однократність дії», «адвербіалізація дії» - в українській мові; «місце дії», «кумулятивність дії» - у польській мові). Кількісні підрахунки дозволяють стверджувати, що частиномовні блоки польської мови вдвічі більше наповнені (див. Таблицю 4). Більша в польській мові й максимальна глибина семантичної позиції «опредметнена дія» та лише поодинокі твірні не породжують похідні. Майже вдвічі вища середня кількість дериватів, які припадають на одне мотивувальне слово в польській мові в порівнянні з українською. 


\section{СПИСОК ЛІТЕРАТУРИ}

(REFERENCES)

Arutiunova, N. D. (1976). Predlozheniye i ego smysl. M. : Nauka.

Bezpoiasko, O. K., Horodenska, K. H., Rusanivskyi, V. M. (1993). Hramatyka ukrainskoi movy. K. : Lybid.

Buzashiova, K. (1987). Vozmozhnosti i granitsy modelirovaniya na urovne slovoobrazovatelnykh paradigm (ss. 14-19). Sopostavitelnoye izucheniye slovoobrazovaniya slavyanskikh yazykov. M. : Nauka.

Buzassyova, K. (1974). Simantická struktura slovenskych deverbativ. Bratislava.

Greshchuk, V. V., Bachkur, R. O., Dzhochka, I. F., Poslavska, N. M. (2007). Narysy z osnovotsentrychnoi deryvatolohii. Ivano-Frankivsk : Misto NV.

Hramatyka suchasnoi ukrainskoi literaturnoi movy. Morfolohiia (2017). [avtory: I. R. Vykhovanets, K. H. Horodenska, A. P. Zahnitko, S. O. Sokolova; za red. K. H. Horodenskoi]. K. : Vydavnychyi dim Dmytra Buraho.

Hrytsyk, N. I. (1979). Diieslova nablyzhennia z prefiksom pry- u zistavlenni z rosiiskymy, (ss. 70-75). Movoznavstvo. № 6.

Hrytsyk, N. I. (1980). Semantyko-stylistychna kharakterystyka diiesliv iz znachenniam prybuttia, (ss. 82-88). Movoznavstvo. № 4.

Iaroshenko, N. (2005). Zistavnyi analiz slovotvirnykh paradyhm diiesliv sazhat, sadyty i sadzic u rosiiskii, ukrainskii i polskii movakh XIKX-XX st. (ss. 305-309) Linhvistychni studii: zb. nauk. prats. Donetsk : DonNU, Vyp. 13.

Khamidullina, A. M. (1981) Otglagol’ny`e imena deyatelya v onomasiologicheskom aspekte (ss. 67-74). Issledovaniya po semantike. Leksicheskaya i semanticheskaya semantika. Ufa: Bashkirskij gos. un-t.

Klimenko, N. F. (1991). Slovoobrazovatelnyye gnezda slov kak obyekt tipologicheskogo izucheniya (ss. 81-83). Aktualnyye problemy russkogo slovoobrazovaniya : materialy VI resp. nauchn.prakt. konf. Samarkand.

Klymenko, N. F. (2004). Slovotvirna paradyhma (s. 619). Ukrainska mova. Entsyklopediia (2-e vyd., zi zmin. i dop.). K. : Vydavnytstvo «Ukrainska entsyklopediia» im. M. P. Bazhana.

Klymenko, N. F. (2008). Dyferentsiini ta intehratsiini protsesy v leksytsi ta slovotvorenni suchasnoi ukrainskoi movy. Movoznavstvo, № 2-3, 136-147.

Kushlyk, O. P. (2015). Slovotvirna paradyhmatyka pokhidnykh diiesliv v ukrainskii movi. Drohobych : Kolo.

Malankowska-Statkiewicz Marta (2017) Potencjał słowotwórczy wybranych czasowników dźwiękonaśladowczych w języku czeskim i polskim (ss. 255-265). Slavica Wratislaviensia. Opole : Wyd-wo Uniwersytetu Opolskiego, Volum 165.

Mykhailyk, R. P. (1995). Semantyko-hramatychna struktura diiesliv na -sia v suchasnii ukrainskii movi (Avtoref. dys. ...kand. filol. nauk: 10.02.01). Kyiv.

Saykiyeva, S. M. (1970). Glagoly dvizheniya-peremeshcheniya v sovremennom russkom yazyke (Avtoref. dis. ... kand. filol. nauk). Alma-Ata.

Sehin, L. V. (2003). Strukturno-semantychna typolohiia slovotvirnykh paradyhm diiesliv dynamichnoi prostorovoi lokalizovanosti v ukrainskii i polskii movakh (Avtoref. dys. ... kand. filol. nauk : spets. 10.02.17). Donetsk. 
Sokolova, S. O. (2003). Prefiksalnyi slovotvir diiesliv u suchasnii ukrainskii movi. K. : Nauk. dumka.

Valiukh, Z. O. (2005). Slovotvirna paradyhmatyka imennyka v ukrainskii movi. Kyiv-Poltava : ASMI.

Valiukh, Z. O. (2013). Slovotvirna paradyhma yak obiekt zistavnoi typolohii, (ss. 6-10). Naukovyi visnyk kafedry YuNESKO Kyivskoho natsionalnoho linhvistychnoho universytetu. Filolohiia, pedahohika, psykholohiia. Vyp. 27. URL : http://nbuv.gov.ua/UJRN/Nvkyu_2013_27_3

Yantsenetskaya, N. M. (1991). Semanticheskiye voprosy slovoobrazovaniya: proizvodyashcheye slovo. Tomsk : Izd-vo Tomsk. un-ta.

Zemskaya, E. A. (1978). O paradigmaticheskikh otnosheniyakh v slovoobrazovanii. (ss. 63-77). Russkiy yazyk: voprosy ego tstorii i sovremennogo sostoyaniya. Vinogradovskiye chteniya I-VIII. Moskva : Nauka.

Zemskaya, E. A., Ermakova, O. P., Rudnik-Karvat, Z. (1993). Teoreticheskiye problemy sopostavitelnogo izucheniya slovoobrazovaniya slavyanskikh yazykov (semantiko-funktsionalnyy aspekt). (ss. 248-263). Slavyanskoye yazykoznaniye. KhI Mezhdunar. syezd slavistov. Doklady rossiyskoy delegatsii: sb. dokladov. M. : Nauka.

Zych, A. (2004). Paradygmat słowotwórczy jako jednostka badań konfrontatywnych (ss. 129140). Język rosyjski $w$ konfrontacji $z$ językami Europy $w$ aspekcie lingwokulturoznawczym. Red. P. Czerwiński, H. Fontański. Katowice.

\section{СПИСОК ДЖЕРЕЛ ІЛЮСТРАТИВНОГО МАТЕРІАЛУ}

SUM - (1970-1980) Slovnyk ukrainskoi movy, t. 1-11 t. K. : Nauk. dumka.

SUMH - Hrinchenko B. D. (1996) Slovar ukrainskoi movy, t. 1-4. K. : Nauk. dumka.

VTSSUM - (2001) Velykyi tlumachnyi slovnyk suchasnoi ukrainskoi movy. K.; Irpin: VTH «Perun».

VZOSSUL - (2003) Velykyi zvedenyi orfohrafichnyi slovnyk suchasnoi ukrainskoi leksyky. K.; Irpin : VTF «Perun».

SJPD - (1958-1969) Słownik języka polskiego, t. 1-11/ red. naczelny W. Doroszewski. Warszawa : Wiedza powszechna.

SJPK - (1900-1933) Słownik języka polskiego, t. 1-8/ pod red. I. Karłowicza i in. Warszawa : Wyd-wo Kasy im. Minowskiego.

SGSWJO - (2004) Słownik gniazd słowotwórczych wspótczesnego języka ogólnopolskiego. T. 3. Gniazda odczasownikowe / M. Skarżyński oraz M. Berend [et al.]. Kraków: T-wo wyd-cze «Historia Jagellonica», cz. I (A-O), cz. II (P-Ż). 